\title{
Perceptions of Tax Compliance by SMEs and Tax Practitioners in New Zealand: A Divergent View?
}

\author{
SUE YONG AND BRETT FREUDENBERG
}

Sue Yong is a senior lecturer in the Business School at Auckland University of Technology and Brett Freudenberg is a professor in the Business School at Griffith University, Australia.

Despite the economic importance of small and medium enterprises (SMEs), little is known about their tax compliance perceptions, which may influence their compliance behaviour. This is particularly so in relation to comparing the tax perceptions of New Zealand SMEs and their tax practitioners. This article reports on a qualitative study which examined the tax compliance perceptions of New Zealand SMEs and their tax practitioners. The findings of this study reveal that SMEs' perceptions of tax compliance are multifaceted and include legal factors, compliance costs, economic considerations and perceptions of "others". On the other hand, tax practitioners generally have a narrow context focusing mainly on compliance cost and legal obligations. The tax policy implications from this study include that it can potentially assist tax authorities to design and implement strategies to influence SMEs' compliance behaviours. Also, for tax practitioners it illustrates their important role in reducing the stress of their SME clients by assisting them through education, including how to use accounting reports for compliance and business control purposes.

\subsection{INTRODUCTION}

Tax compliance research has gained momentum over the last five decades, and research has found tax compliance to be dependent on numerous factors including deterrence, economic, social, norms, attitudinal, psychological, fairness, trust, cultural, political, opportunities and perception factors. ${ }^{1}$ Tax compliance is a complex phenomenon due to human behaviours and the context in which it is applied. With that, the Organisation for Economic Co-operation and Development (OECD) has called for more conceptual and empirical work to understand the drivers of tax compliance behaviours. ${ }^{2}$ Understanding tax compliance drivers can potentially assist tax authorities to design and implement strategies to influence compliance behaviours. Tax compliance is particularly eminent for self-assessment tax regimes where voluntary compliance can directly influence tax revenues.

Small and medium enterprises (SMEs) can be considered the backbone of most economies, as they can comprise more than 90 per cent of all enterprises in a country. ${ }^{3}$ New Zealand defines SMEs as enterprises

1 Maryann Richardson and Adrian J Sawyer "A Taxonomy of the Tax Compliance Literature: Further Findings, Problems and Prospects" (2001) 16 Australian Tax Forum 137; Natrah Saad "Fairness Perceptions and Compliance Behaviours: New Zealand Evidence" (2011) 17 NZJTLP 33; Sue Yong and others “Tax Compliance in the New Millennium” (paper presented to Australasian Teachers Tax Conference, Curtin University, Perth, Australia, January 2019); and Binh Tran-Nam "Tax Compliance Research: An Economic Perspective" (2003) 9 NZJTLP 455.

2 OECD Forum on Tax Administration: SME Compliance SubGroup - Understanding and Influencing Taxpayers' Compliance Behaviour 2010 (OECD Publishing, Paris, 2010).

3 OECD Taxation of SMEs in OECD and G20 Countries (OECD Tax Policy Studies, OECD Publishing, Paris, 2015). 
with 19 or fewer employees. ${ }^{4}$ In New Zealand, SMEs are the second-largest taxpayer group after individual taxpayers. ${ }^{5}$ New Zealand SMEs are a significant contributor to the country's employment, economic growth and innovation, and they operate in diverse industries. ${ }^{6}$ However, SMEs do face challenges, including financial constraints, compliance costs, and restricted management capacity, and this in part can relate to the limited resources that they have by the very fact of being small. ${ }^{7}$ Prior literature demonstrates that generally SMEs are internally controlled by the owner with limited funds. ${ }^{8}$ Furthermore, poor financial management skills with weak record-keeping are commonly found in SMEs. ${ }^{9}$ With finance being an issue for SMEs, tax payments can have a significant impact on their business liquidity.

Due to SMEs' importance but perceived challenges, governments globally have undertaken measures to assist SMEs. For example, the New Zealand Government undertook several reforms, including providing government support in terms of advice and resourcing for compliance purposes. ${ }^{10}$ These reforms appear to have had some success, as New Zealand has been ranked first in the world in terms of ease of doing business ${ }^{11}$ which could partly be attributable to the small size of the New Zealand population and economy.

The increase in tax compliance research has mostly focused on individual taxpayers, with relatively few researching about SMEs. Although the number of research studies focusing on SMEs has risen, ${ }^{12}$ there is still insufficient knowledge about their tax perceptions. Hence, to what extent SMEs are fully tax complaint is worthy of further research. Some prior literature indicates that SME taxpayers are responsible, law-abiding, conscientious, ambitious and ethical. ${ }^{13}$ SMEs can have a strong positive attitude to comply but have due concerns with tax penalties and interest. ${ }^{14}$ Unfortunately, their strong attitude toward compliance may be negatively influenced by limited tax literacy. ${ }^{15}$

Nevertheless, SMEs are considered a high-risk tax group with one of the highest tax non-compliance statistics. ${ }^{16}$ This non-compliance can be attributable to having opportunities to evade taxes, including participating in the cash economy. ${ }^{17}$ The non-compliance may be unintentional, as SMEs face challenges

4 Ministry of Economic Development SMEs in New Zealand: Structure and Dynamics 2011 (September 2011) at 10.

5 Inland Revenue "Registered Customers by Customer Group 2008 to 2017” (16 October 2018) <www.ird.govt.nz/>.

6 Ministry of Business, Innovation and Employment Small Businesses in New Zealand: How do they compare with larger firms?(June 2017).

7 Melissa Belle Isle and Brett Freudenberg “Calm Waters: GST and Cash Flow Stability for Small Businesses in Australia” (2015) 13 eJournal of Tax Research 492.

8 Leonardo Liberman-Yaconi, Terrena Hooper and Kate Hutchings “Toward a Model of Understanding Strategic Decision-Making in Micro-Firms: Exploring the Australian Information Technology Sector” (2010) 48 Journal of Small Business Management 70.

9 Rob MacGregor and Lejla Vrazalic “A Profile of Australian Regional SME Non-Adopters of E-Commerce” (2008) 16 Small Enterprise Research 27.

10 Ministry of Business Innovation and Employment, above n 6.

11 World Bank Doing Business 2017: Equal Opportunity for All (February 2019).

12 See Yong and others, above n 1; Cynthia Coleman and Lynne Freeman "The Development of Strategic Marketing Options Directed at Improving Compliance Levels in Small Business” (1994) 11 Australian Tax Forum 347; and Belle Isle and Freudenberg, above $n 7$.

13 Eliza Ahmed and Valerie Braithwaite "Understanding Small Business Taxpayers: Issues of Deterrence, Tax Morale, Fairness and Work Practice” (2005) 23 International Small Business Journal 539.

14 Brett Freudenberg and others “Tax Literacy of Australian Small Businesses” (2017) 18 Journal of Australian Taxation 21.

15 Freudenberg and others, above $\mathrm{n} 14$.

16 OECD Taxation of SMEs: Key Issues and Policy Considerations (OECD Tax Policy Studies, OECD Publishing, Paris, 2009).

17 Cash Economy Task Force The Cash Economy Under the New Tax System: Report to the Commissioner of Taxation (Commonwealth of Australia, September 2003). 
in meeting complex regulatory requirements. ${ }^{18}$ This complexity can result in high compliance costs, which can be regressive for small businesses. ${ }^{19}$

In addition to paying their tax liabilities, SMEs are also tax collectors on behalf of governments, particularly in terms of value-added and employment-related taxes. ${ }^{20}$ Being tax collectors requires them to account for and return these tax monies to the tax authority, thus increasing their tax compliance costs. For New Zealand SMEs, taxation issues are one of their main concerns, ${ }^{21}$ and business failures have been associated with poor record-keeping for tax purposes. ${ }^{22}$

Prior research has shown that taxpayers' values, attitudes and perceptions are pivotal in terms of tax compliance. ${ }^{23}$ In particular, SMEs' tax compliance decisions are heavily influenced by high tax rates, perceptions of tax fairness, government spending priorities, tax service quality, and personal norms. ${ }^{24}$ SMEs may feel disgruntled as they are likely to incur tax liabilities at year-end due to lack of withholding taxes during the year. ${ }^{25}$

New Zealand research about tax perceptions and fairness has produced mixed results. Hasseldine, Kaplan and Fuller showed an overall negative perception of the tax system. ${ }^{26}$ Tan found that taxpayers' perceptions of fairness were negatively impacted by their perceptions of unfair distribution of tax burden, and differential tax treatments between middle-income earners and the wealthy. ${ }^{27}$ In a study by Saad, tax knowledge and tax complexity had a significant impact on the fairness perceptions by taxpayers. ${ }^{28}$ However, Saad found that the increase in tax knowledge could improve fairness perceptions, and that "tax fairness" can be related to the administration of tax laws, government spending and the opportunity to evade taxes. ${ }^{29}$ Unfortunately, Saad's research was limited to perceptions of individuals and not business taxpayers, as the perceptions between these two groups may differ.

SMEs do not generally operate in the tax system alone, and they can be reliant on tax practitioners to assist them with their tax compliance obligations. New Zealand business owners value tax practitioners

18 Margaret McKerchar "The Effects of Complexity on Unintentional Noncompliance for Personal Taxpayers in Australia" (2002) 17 Australian Tax Forum 3.

19 Philip Lignier and Chris Evans "The Rise and Rise of Tax Compliance Costs for the Small Business Sector in Australia" (2012) 27 Australian Tax Forum 615.

20 David Joulfaian and Mark Rider "Differential Taxation and Tax Evasion by Small Business” (1998) 51 National Tax Journal 675.

21 Business NZ-KPMG Summary Report of the Business New Zealand - KPMG Compliance Cost Survey October 2008 (Business NZ-KPMG, 2008).

22 Semisi Prescott and Keith Hooper "Commons and Anti-Commons: Tongan Business Experiences in New Zealand" (2009) 21 Pacific Accounting Review 286.

23 John Cullis and Alan Lewis "Why people pay taxes: From a conventional economic model to a model of social convention" (1997) 18 Journal of Economic Psychology 305; Valerie Braithwaite "Perceptions of Who's Not Paying Their Fair Share" (2003) 38 Australian Journal of Social Issues 335; and George Gilligan and Grant Richardson "Perceptions of Fairness and Tax Compliance in Australia and Hong Kong - A Preliminary Study" (2005) 12 Journal of Financial Crime 331.

24 Banele Dlamini "Determinants of Tax Non-Compliance Among Small and Medium Enterprises in Zimbabwe” (2017) 9 Journal of Economics and Behavioral Studies 242; and Michael Wenzel "Motivation or Rationalisation? Causal Relations Between Ethics, Norms and Tax Compliance” (2005) 26 Journal of Economic Psychology 491.

25 Bernadette Kamleitner, Christian Korunka and Erich Kirchler “Tax compliance of small business owners” (2012) 18 International Journal of Entrepreneurial Behaviour \& Research 330.

26 John Hasseldine, Steven Kaplan and Lori Fuller “Characteristics of New Zealand tax evaders: A note” (1994) 34 Accounting and Finance 79.

27 Lin Mei Tan "Taxpayers' Perceptions of Fairness of the Tax System - A Preliminary Study" (1998) 4 NZJTLP 59.

28 Saad, above $\mathrm{n} 1$.

29 Saad, above $\mathrm{n} 1$, at 39 and 54. 
due to their tax advisory and intermediary roles with the tax authority. ${ }^{30}$ New Zealand SMEs consider their accountants/practitioners to be the most frequently used, the most helpful and the most significant source of help compared to other sources of help..$^{31}$ Recent research shows more European and Polynesian SME operators use the services of accountants/practitioners compared to that of Asian SME operators. ${ }^{32}$ Therefore, it would appear beneficial to understand the perception of SME tax practitioners to get an overall sense of what they observe as tax compliance by their SME clients.

This article aims to examine the tax compliance perceptions of two stakeholder groups in New Zealand: SME taxpayers and tax practitioners. In particular, the overall research question is to determine whether these compliance perceptions are congruent with each other. Specifically, this study will identify the pertinent compliance factors relevant to each group and whether there exists a tax compliance perception gap. The interviews account for 37 SME taxpayers and eight tax practitioners which will be analysed in conjunction with Inland Revenue reports.

This study is unique for several reasons. First, it compares the tax perceptions of multiple stakeholder groups, ${ }^{33}$ unlike the majority of the studies which tend to concentrate on one stakeholder group. ${ }^{34}$ Second, it is important to identify any differences in tax perceptions, as these provide impetus and recommendations to improve voluntary compliance. This research is also relevant as tax practitioners do play critical roles in assisting SMEs. Accordingly, if tax practitioners' perceptions are different from those of their SME clients, it may inhibit effective advice.

This article is structured as follows. The next section discusses prior literature, which focuses broadly on tax compliance in terms of its meaning, cost, and the factors that may aid or hinder tax compliance. The research methodology then follows this in Section 3. The fourth section details the findings, with analysis and recommendations in Section 5. Section 6 concludes with suggestions for future research.

\subsection{LITERATURE REVIEW}

In this section, the meaning of tax compliance will be canvassed, and tax compliance factors will be highlighted. For this article, the authors have adopted the definition of tax compliance, as suggested by Ohms, Oleson and Khin-Carter as: ${ }^{35}$

the actions of a taxpayer in engaging in the set of statutory obligations cast upon them in respect of their annual total tax liability to register, record and report, return and enable assessment, pay and participate in any post-assessment adjustment process (audit and dispute resolution).

30 Lin Mei Tan, Valerie Braithwaite and Monika Reinhart "Why do small business taxpayers stay with their practitioners? Trust, competence and aggressive advice” (2014) 30 International Small Business Journal 1.

31 Business NZ-KPMG, above n 20; and Kate Lewis and others Family, Friends and Government Agencies: A Report on SMEs and the Support Infrastructure (New Zealand Centre for SME Research, 2005).

32 Sue Yong, Deryl Northcott and Keith Hooper “Culture and the Tax Compliance Behaviour of Ethnic Business Owners” (2014) 20 NZJTLP 71.

33 See these studies which have researched more than one stakeholder group simultaneously: Anne Christensen "Evaluation of tax services: A client and preparer perspective” (1992) 14 The Journal of the American Taxation Association 60; and T Porcano and C Price "Some Evidence on the Association Between Judgement Criteria and Fairness Perceptions" (1992) 4 Advances in Taxation 183.

34 See these studies which have researched one stakeholder group: Hijattulah Abdul-Jabbar and Jeff Pope "Tax Attitudes and Compliance among Small and Medium Enterprises in Malaysia" (2009) 15 NZJTLP 198; and Joel Slemrod and Nikki Sorum “The Compliance Cost of the U.S. Individual Income Tax System” (1984) 37 National Tax Journal 461.

35 Chris Ohms, Karin Olesen and Natalie Khin-Carter “Taxpayer Compliance Models: A Literature Review and Critique” (2015) 21 NZJTLP 427 at 428. 
This definition encapsulates the multi-dimensional nature of tax compliance to include recording, reporting, timely payment and abiding with legislations. On the other hand, the tax authority's view on compliance is as follows: "The integrity of the New Zealand tax system is based on individuals and businesses meeting their tax obligations on time and in full”. ${ }^{36}$ This view focuses on law-abiding taxpayers, and statutory requirements are the main drivers for compliance. In summary, the definitions of tax compliance by academics and tax authorities tend to concentrate on the outcome of tax compliance rather than the factors that contribute to tax compliance.

Tax compliance is complex as it involves human behaviour. ${ }^{37}$ Geibart considers tax compliance as a means of traversing a maze of court cases, regulations, exceptions and exemptions, which may lead to confusion for both taxpayers and tax practitioners. ${ }^{38}$ Tax compliance requires an understanding of tax laws and administrative skills in accounting and paying the tax liability. Considering the nature of SMEs, such requirements can be difficult.

\subsection{Data on Tax Compliance in New Zealand}

Part of tax compliance is the lodgement of tax returns on time. Table 1 details the percentage of returns filed on time with Inland Revenue by business customers from 2007 to 2016. Income tax returns have the lowest on-time lodgement (74 per cent) compared to goods and services tax (GST) and pay-as-you-earn (PAYE) (about 88 per cent). It could be that the frequency of GST and PAYE returns requires better reporting systems or that income tax returns involve multiple issues and are more difficult to complete.

Table 1: Percentage of Returns Filed on Time by Business Customers, 2007 to $2016^{39}$

\begin{tabular}{|l|c|c|c|}
\cline { 2 - 4 } \multicolumn{1}{c|}{} & \multicolumn{3}{c|}{ Tax Type } \\
\cline { 2 - 4 } \multicolumn{1}{c|}{} & GST & PAYE & Income Tax \\
\cline { 2 - 4 } \multicolumn{1}{c|}{} & $\mathbf{\%}$ & $\mathbf{\%}$ & $\mathbf{\%}$ \\
\hline Mar-07 & 87.1 & 88.0 & 71.5 \\
\hline Mar-08 & 85.3 & 87.0 & 71.1 \\
\hline Mar-09 & 86.7 & 87.5 & 71.2 \\
\hline Mar-10 & 87.6 & 87.0 & 69.8 \\
\hline Mar-11 & 87.1 & 86.3 & 70.3 \\
\hline Mar-12 & 87.6 & 86.5 & 69.3 \\
\hline Mar-13 & 88.5 & 86.8 & 71.0 \\
\hline Mar-14 & 88.1 & 87.4 & 73.6 \\
\hline Mar-15 & 88.7 & 87.5 & 73.2 \\
\hline
\end{tabular}

36 Penny Salmon and Research NZ SME tax compliance cost: A qualitative investigation to identify steps Inland Revenue could take to reduce effort and compliance cost of SMEs (Inland Revenue National Research and Evaluation Unit, November 2014 ) at 1.

37 See James Alm, Gary McClelland and William Schulze "Why do people pay taxes?" (1992) 48 Journal of Public Economics 21; Icek Ajzen and Martin Fishbein “The theory of planned behaviour” (1991) 55 Organizational Behavior and Human Decision Processes 179; Alan Lewis The Psychology of Taxation (M Robertson, Oxford, 1982); and Kent Smith and Karyl Kinsey "Understanding Taxpaying Behaviour: A Conceptual Framework with Implications for Research" (1987) 21 Law \& Society Review 639.

38 N Geibart “Digging Out the Complexities of Tax Compliance” (2014) 4 The Business 32.

39 Adapted from Inland Revenue "Percentage of returns filed on time 2007 to 2016" < https://classic.ird.govt.nz/>. 


\begin{tabular}{|l|l|l|l|}
\hline Mar-16 & 88.9 & 87.9 & 73.9 \\
\hline
\end{tabular}

Tax compliance involves the actual payment of tax. When finances are tight, SMEs may hold off paying taxes and use tax monies to finance their business operations. Business tax debts are high in New Zealand, and the two largest overdue tax debts are GST and income tax: see Table 2. Income tax debt is, on average, nearly double that of GST. Overall, this data would tend to indicate that income tax is lodged late and paid late.

Table 2: Overdue Tax Debt as at 30 June (\$ Million) from Businesses ${ }^{40}$

\begin{tabular}{|l|r|r|r|r|r|}
\hline Debt Type & $\mathbf{2 0 1 3}$ & $\mathbf{2 0 1 4}$ & $\mathbf{2 0 1 5}$ & \multicolumn{1}{c|}{$\mathbf{2 0 1 6}$} & \multicolumn{1}{c|}{$\mathbf{2 0 1 7}$} \\
\hline GST & $1,873.9$ & $1,775.5$ & $1,527.5$ & $1,369.5$ & 825.6 \\
\hline Income tax & $2,365.70$ & $2,519.60$ & $2,653.0$ & $2,562.4$ & $1,556.10$ \\
\hline
\end{tabular}

Inland Revenue reports that SMEs owed about a third of the $\$ 5.15$ billion of tax debt in $2010 .{ }^{41} \mathrm{~A}$ large concentration of this debt is with 10 per cent of SMEs (11,000 SMEs) who owed half of the debt. ${ }^{42}$ About one-third of this debt is incurred through penalties from income tax, GST and PAYE. The self-employed owed the highest amounts of tax debts compared to other businesses. ${ }^{43}$ Also, half of the tax debt was owed by SMEs from Auckland, ${ }^{44}$ as it has the highest concentration of SMEs in the country. The average debt from Auckland was also higher than in other regions. Table 3 further illustrates the percentage of the tax bill by SME based on annual turnover in 2010, which demonstrates the regressive nature of tax debts, particularly for smaller businesses.

Table 3: Percentage of Tax Bill by SME Annual Turnover in $\mathbf{2 0 1 0}^{45}$

\begin{tabular}{|c|c|}
\hline Percentage of SMEs Tax Bill & Annual Turnover \\
\hline $6.5 \%$ & Up to $\$ 50,000$ \\
\hline $3.8 \%$ & $\$ 50,001-\$ 100,000$ \\
\hline $2.0 \%$ & $\$ 100,001-\$ 500,000$ \\
\hline $1.7 \%$ & $\$ 500,001-\$ 100$ million \\
\hline
\end{tabular}

Overall, it appears that SMEs have struggled to meet their full tax compliance obligations, especially when it comes to income tax lodgement and payment.

\subsection{Compliance Costs}

Compliance costs include three major components: monetary costs, time costs and psychological costs to taxpayers. ${ }^{46}$ Monetary costs include money spent on tax professionals and expenses relating to taxation guides, books, communication and other incidental costs. Time costs are incurred by the taxpayers mainly on record-keeping for tax purposes and preparing the tax details for tax authorities or tax professionals.

40 Inland Revenue Annual Report 2017 (2017) at 41.

41 Inland Revenue Identifying Sanction Thresholds Among SME Tax Debtors: An Overview (2011).

42 Inland Revenue, above n 41, at 10.

43 Inland Revenue, above $\mathrm{n} 41$.

44 Inland Revenue, above n 41, at 11.

45 Inland Revenue, above n 41, at 14.

46 Cedric Sandford and John Hasseldine The Compliance Costs of Business Taxes in New Zealand (Institute of Policy Studies, Victoria University of Wellington, Wellington, 1992). 
Psychological costs are the mental stress relating to tax compliance activities. ${ }^{47}$ Such psychological costs can be problematic for SMEs as the owner can be heavily involved with the business operations and tax obligations. ${ }^{48}$ The stress level of SMEs related to taxation issues (and not other business issues) is detailed in Table 4. Unfortunately, that study did not consider other potential issues that could cause stress and whether these were more or less than the stress in relation to tax. In 2009, the stress averaged from 3.0 to 3.4, with micro-businesses having the highest stress level.

Table 4: Level of Stress by Business Size ${ }^{49}$

\begin{tabular}{|l|c|c|}
\hline Number of Employees & $\mathbf{2 0 0 4}$ & $\mathbf{2 0 0 9}$ \\
\hline Nil & 3.3 & 3.0 \\
\hline Micro (1-5) & 3.6 & 3.4 \\
\hline Small (6-19) & 3.5 & 3.2 \\
\hline Medium (20+) & 3.5 & 3.3 \\
\hline All personnel & 3.4 & 3.2 \\
\hline
\end{tabular}

Level of stress by business size (number of employees) based on a 7-point scale of stress, where $1=$ no stress and $7=$ extremely stressful.

Based on a 7-point scale of stress, the most stressful activity for SMEs relates to filing provisional tax at 3.9 and 3.5 for 2004 and 2009, respectively. This is then followed by filing GST at a stress level of 3.8 and 3.4 for 2004 and 2009, respectively. ${ }^{50} \mathrm{~A}$ further study commissioned by Inland Revenue on $25 \mathrm{SME}$ taxpayers found that of all the government agencies, Inland Revenue was repeatedly listed as the agency requiring "a lot of effort" to deal with: see Table 5.

Table 5: Level of Effort Dealing with Government Departments ${ }^{51}$

\begin{tabular}{|l|c|c|c|}
\hline Government Department & $\begin{array}{l}\text { Not Much } \\
\text { Effort }\end{array}$ & $\begin{array}{l}\text { Moderate } \\
\text { Effort }\end{array}$ & $\begin{array}{l}\text { A Lot of } \\
\text { Effort }\end{array}$ \\
\hline Inland Revenue & 5 & 8 & 12 \\
\hline ACC & 10 & 11 & 4 \\
\hline Customs & 3 & 0 & 2 \\
\hline Ministry of Business, Innovation and Employment & 6 & 5 & 2 \\
\hline Statistics New Zealand & 4 & 6 & 2 \\
\hline NZ Transport Agency & 10 & 2 & 1 \\
\hline Department of Internal Affairs & 2 & 2 & 0 \\
\hline Ministry of Primary Industries & 3 & 0 & 0 \\
\hline NZ Trade and Enterprise & 0 & 1 & 0 \\
\hline
\end{tabular}

47 Binh Tran-Nam "Tax Compliance Research: An Economic Perspective" (2003) 9 NZJTLP 455.

48 Nahida Faridy and others "The Hidden Compliance Cost of VAT: An Exploration of Psychological and Corruption Costs of VAT in a Developing Country” (2016) 14 eJournal of Tax Research 166.

49 Inland Revenue SME tax compliance costs 2004 to 2014: Evaluation report 2 (June 2014).

50 Inland Revenue, above n 49.

51 Penny Salmon and Research NZ, above n 36. 


\begin{tabular}{|l|l|l|l|}
\hline Local government & 2 & 5 & 6 \\
\hline
\end{tabular}

Inland Revenue's research showed that tax payments remained an issue for SMEs, and they perceived themselves as collecting some taxes on behalf of Inland Revenue, with no real benefit or recompense to themselves. ${ }^{52}$ The research claimed that Inland Revenue's lack of customer-orientation underpinned all the practical problems that SMEs faced..$^{53}$ Additionally, power imbalance was identified as one of the main concerns, with harsh and inflexible rules relating to penalties for businesses. ${ }^{54}$ Devos found that increases in penalties in the New Zealand tax regime have had little impact on the level of taxpayer non-compliance..$^{55}$

SMEs face regressive tax compliance costs, ${ }^{56}$ which can be aggravated by their low proficiency in administration and record keeping. ${ }^{57}$ The OECD states that: ${ }^{58}$

the most important issues affecting SMEs are the disproportionately high impact of regulatory requirements and tax compliance cost. The significant fixed costs associated with compliance represent a higher cost for SME as a percentage of sales and income, and consequently, have a greater adverse impact upon SMEs than larger businesses.

The regressive compliance cost is an added economic burden on SMEs. Selected data provided by Inland Revenue illustrates the high number of tax compliance hours incurred by SMEs in 2004 and 2009. SMEs incurred 93.3 median hours annually in 2004 and 77 median hours in 2009, with the highest amount of time spent on filing GST. ${ }^{59}$ More recently, there have been improvements in the median time SMEs spent on tax compliance activities on an annual basis since 2014: see Table 6. This could suggest that less time is being spent on tax compliance activities, which may be due to numerous factors, including the better use of technology and more assistance from Inland Revenue. ${ }^{60}$

\section{Table 6: Median Annual Time on SME Tax Compliance Activities ${ }^{61}$}

\begin{tabular}{|l|c|}
\hline Year & The Median Time Spent on Annual Tax Compliance Activities \\
\hline 2013 & 36 hours \\
\hline 2014 & 55 hours \\
\hline 2015 & 48 hours \\
\hline 2016 & 36 hours \\
\hline 2017 & 27 hours \\
\hline
\end{tabular}

Compliance costs are one of the main challenges SMEs face regarding their viability and growth. SMEs often do not have sufficient organisational and financial resources to meet their tax obligations effectively

52 Penny Salmon and Research NZ, above n 36, at 12.

53 Penny Salmon and Research NZ, above n 36, at 16.

54 Penny Salmon and Research NZ, above n 36.

55 Ken Devos "Penalties and Sanctions for Taxation Offences in New Zealand: Implications for Taxpayer Compliance" (2004) 10 NZJTLP 212 at 234.

56 Lignier and Evans, above n 19.

57 Chris Evans, Shirley Carlon and Darren Massey "Record Keeping Practices and Tax Compliance of SMEs" (2005) 3 eJournal of Tax Research 288.

58 OECD, above $\mathrm{n} 3$, at 13 .

59 Inland Revenue, above n 41, 2.

60 For a discussion about how technology could ease compliance burden see: Simon James, Adrian Sawyer and Tamer Budak (eds) The Complexity of Tax Simplification: Experiences from around the world (Palgrave Macmillan, United Kingdom, 2016).

61 Inland Revenue, above n 39, 71. 
and efficiently compared to larger enterprises because they are small, which in part is due to economies of scale. They do not have the same resources as larger businesses. Instead of having in-house accountants, many SMEs resort to using the services of external accountants/tax practitioners. ${ }^{62}$ SMEs are also shown to have less capacity to cope with the burden of tax regulations. ${ }^{63}$ SMEs' role as tax collectors, with obligations to withhold taxes on employment and GST, can impose additional burdens for them. ${ }^{64}$

Increased complexity of a tax system could drive up compliance costs. Richardson concludes that complexity could be an important determinant of non-compliance. ${ }^{65}$ Furthermore, complexity also influences tax perceptions significantly. ${ }^{66}$

\subsection{Compliance Factors for SMEs}

SMEs generate a significant share of all taxable business income in most economies. ${ }^{67}$ They have been renowned for their low tax compliance statistics, ${ }^{68}$ and they exhibit high distrust towards tax authorities. ${ }^{69}$ Some SMEs do transact (or part of) their business in the informal/cash economy, ${ }^{70}$ and it is important to have a greater understanding of the factors influencing their compliance decisions. ${ }^{71}$

An OECD report explored an ethnographic survey undertaken by the United Kingdom's Revenue Authority regarding the motivation behind 16 SMEs' compliance with tax regulations. ${ }^{72}$ The research took six months, where SMEs were observed in their day-to-day operations. The major findings from this research were:

- tax is seen as complicated and many SMEs have poor tax habits. They also rely heavily on tax practitioners;

- the tax authorities are feared. Fear reinforces a lack of engagement, which combines with tax being seen as dull and complicated;

- most SMEs work to a steady rhythm of orders, customer interactions, deliveries and sales. Tax, however, does not fit into this natural rhythm as it often has future compliance dates. This inadvertently encourages SMEs to put off dealing with their tax affairs; and

62 OECD Rethinking Tax Services - The Changing Role of Tax Service Providers in SME Tax Compliance (OECD Publishing, Paris, 2016) at 48.

63 Brett Freudenberg and others “A Comparative Analysis of Tax Advisers' Perception of Small Business Tax Law Complexity: United States, Australia and New Zealand” (2012) 27 Australian Tax Forum 677.

64 Lynley Woodward and Lin Mei Tan "Small Business Owners' Attitudes Toward GST Compliance: A Preliminary Study" (2015) 30 Australian Tax Forum 517.

65 Grant Richardson “Determinants of Tax Evasion: A Cross-Country Investigation” (2006) 15 Journal of International Accounting, Auditing and Taxation 150.

66 Saad, above $\mathrm{n} 1$.

67 OECD, above n 62.

68 Australian Taxation Office Small Business, Tax and the Cash Economy: We All Play a Part (Australian Government, 2012).

69 G Cooper "Small Business, Big Burden” (1998) 68 Australian CPA 10; Sue Yong and Fiona Martin “Tax Compliance and Cultural Values: The Impact of 'Individualism and Collectivism' on the Behaviour of New Zealand Small Business Owners” (2016) 31 Australian Tax Forum 289.

70 Christopher Bajada Australia's Cash Economy: A Troubling Issue for Policymakers (Routledge, London, 2002).

71 Nahida Faridy, Brett Freudenberg and Tapan Sarker "What's in It for Me? The Potential for Managerial Benefits to Improve Tax Compliance” (2018) 33 Australian Tax Forum 307.

72 OECD, above n 2. 
- SMEs believe in the principle of fair exchange, either in goods or services or as customer satisfaction. Tax compliance, however, is seen as an activity for which SMEs get no return. ${ }^{73}$

One of the potential benefits of tax compliance can be managerial benefits. ${ }^{74}$ Managerial benefits may be derived from keeping tax records by providing businesses with greater insight into their operations and improved decision-making and control. However, research has demonstrated that for small businesses, if it had not been a legal requirement to keep records for tax purposes, many would prefer not to have them. ${ }^{75}$ In particular, micro-businesses were unwilling to pay for accounting information in the absence of tax compliance obligations. ${ }^{76}$ Also, there are several factors inhibiting SMEs "actually realising” such managerial benefits. Inhibiting factors include the negative perceptions of owner-managers that accounting information is useful, ${ }^{77}$ as well as poor record-keeping and low financial statement literacy. ${ }^{78}$

The perceptions of owner-managers about the usefulness of accounting information may be influenced by their knowledge of accounting and business experience. ${ }^{79}$ New Zealand SME owners believed that the main purpose of record-keeping was for tax purposes. ${ }^{80}$ They placed more importance on keeping up to date with their cash at bank balance, a figure considered to be a measure of their business performance. ${ }^{81}$ Consequently, even though accounting records are used for tax purposes, there is doubt as to whether these records are used for managing their business. ${ }^{82}$

Overall, tax compliance is a multifaceted phenomenon, and it extends beyond the legal and economic factors. It appears that the perceptions of taxpayers can influence how they conduct themselves. SMEs can have a negative perception of the tax system, as it can reduce their financial capacity, increase their cost, be perceived to provide little or no benefit (including managerial benefits), and they can begrudge collecting on behalf of government agencies. Promoting compliance also requires an understanding of the role of tax practitioners as they are one of the factors that can influence SME taxpayers' compliance behaviour.

\subsection{Tax Practitioners and Tax Compliance}

Tax practitioners can play an important role in assisting SMEs to comply with tax requirements. Tax practitioners have been employed by taxpayers to help them minimise audit problems, minimise the taxes payable, reduce the risk of being audited, and avoid making a mistake and being penalised. ${ }^{83}$ Complexity of the tax laws, sources of income, tax rates and ambiguous incomes are some common reasons for taxpayers

73 OECD, above n 2, at 28.

74 Philip Lignier "The Managerial Benefits of Tax Compliance: Perception by Small Business Taxpayers” (2009) 7 eJournal of Tax Research 106.

75 Kamleitner, Korunka and Kirchler, above n 25; and Yong and others, above n 32.

76 Philip Lignier "Measuring the Managerial Benefits of Tax Compliance: A Fresh Approach" (2009) 24 Australian Tax Forum 117 at 129.

77 Lignier, above n 76, at 129.

78 Melissa Belle Isle, Brett Freudenberg and Tapan Sarker "Is the Literacy of Small Business Owners Important for Cash Flow Management?: The Experts' Perspective” (2018) 13 Journal of the Australasian Tax Teachers Association 31.

79 Faridy, Freudenberg and Sarker, above n 71.

80 Yong and Martin, above n 69.

81 Yong, Northcott and Hooper, above n 32.

82 Sue Yong and Fiona Martin “Tax compliance of ethnic minority immigrant entrepreneurs: A social capital perspective” (2017) 15 eJournal of Tax Research 51.

83 Ken Devos and Paul Kenny "An assessment of the Code of Professional Conduct under the TASA 2009 - six years on" (2017) 34 Australian Tax Forum 629; and P Hite, T Stock and C Cloyd "Reasons for Preparer Usage by Small Business Owners: How Compliant are They?" (1992) 37 National Society of Public Accountants 20. 
using tax practitioners. ${ }^{84}$ Tax practitioners can have a significant influence on the compliance landscape, for example, up to 75 per cent of Australian taxpayers relied on their tax practitioners to lodge their tax returns. ${ }^{85}$ The OECD considers the need for tax authorities to work cooperatively with tax practitioners and other parties in order to effectively influence compliance behaviour. ${ }^{86}$ Beyond supporting SMEs in fulfilling their fiscal obligations, tax practitioners also provide business and financial advice. ${ }^{87}$ In New Zealand, tax practitioners/accountants are considered the most valued and most sought after assistance by SMEs. ${ }^{88}$ Tax practitioners can be a recognised and trustworthy source of advice and support for SMEs.

Research demonstrates that SME taxpayers want their tax returns to be accurately prepared by their tax practitioners. ${ }^{89}$ Hite and McGill found that tax professionals can be more aggressive than their clients want them to be, and that clients who disagreed with aggressive tax advice are more likely to change tax practitioners than are clients who disagreed with conservative advice. ${ }^{90}$ Sakurai and Braithwaite found that most taxpayers want the "low risk, no fuss" tax practitioner who was honest and risk-averse ${ }^{91}$ Evidence suggests that those seeking preparers have reporting accuracy as their main goal, and they negatively view their tax practitioners if they are subject to tax audits. ${ }^{92}$

Tan found the role of tax practitioners for SMEs was to assist with filing more "difficult" returns, and because of their costs, they were not used as often. ${ }^{93}$ The taxpayers filed routine returns for GST and PAYE, but the tax practitioners were employed to file more technically challenging returns such as the income tax and fringe benefit tax (FBT) returns. Consequently, while the compliance decision-making of SMEs and their tax practitioners is complex, the authors are not aware of any research that compares and contrasts their perceptions of tax compliance, and what this may mean for overall tax compliance behaviour.

\subsection{RESEARCH METHODOLOGY AND RESEARCH DESIGN}

The literature suggests that there are multi-faceted factors affecting tax compliance and that tax compliance is complex due to human behaviours. ${ }^{94}$ Tax authorities have acknowledged that taxpayers' compliance behaviour is a result of their norms and experiences related to a specific context. The context is the social and economic environment and the society in general, and includes the interactions of the tax

84 Lin Mei Tan and Adrian Sawyer “A Synopsis of Taxpayer Compliance Studies: Overseas vis-a-vis New Zealand” (2003) 9 NZJTLP 431 at 437; C Christian, S Gupta and S Lin "A Comparison of Tax Professionals' Individual and Group Decisions When Resolving Ambiguous Tax Questions” (1993) 46 National Tax Journal 487.

85 Devos and Kenny, above n 83, at 633

86 OECD, above n 2, at 40.

87 OECD, above $\mathrm{n} 62$.

88 Lewis and others, above $\mathrm{n} 31$.

89 Tan, Braithwaite and Reinhart, above n 30.

90 Peggy Hite and Gary McGill "An Examination of Taxpayer Preference for Aggressive Tax Advice” (1992) 45 National Tax Journal 389.

91 Yuka Sakurai and Valerie Braithwaite "Taxpayers' Perceptions of Practitioners: Finding One Who is Effective and Does the Right Thing?” (2003) 46 Journal of Business Ethics 375.

92 Rex Marshall, Robert Armstrong and Malcolm Smith "The Ethical Environment of Tax Practitioners: Western Australian Evidence” (1998) 17 Journal of Business Ethics 1265; Tan, Braithwaite and Reinhart, above n 30; Ken Devos “The impact of tax professionals upon the compliance behaviour of Australian individual taxpayers” (2012) 22 Revenue Law Journal 31; and S Nienaber "Factors that could influence the ethical behaviour of tax professionals" (2010) 18 Meditari Accounting Research 33.

93 Lin Mei Tan "Coping with Tax Obligations: A Preliminary Study of Some Small Firms in New Zealand" (1997) 13 Australian Tax Forum 337.

94 Cullis and Lewis, above n 23; and OECD, above n 62. 
authority with taxpayers. ${ }^{95}$ Hence, Kirchler states that people discussing taxation issues tend to evaluate the interrelationships of fiscal and tax policies, tax spending and their experiences with the tax system. ${ }^{96} \mathrm{It}$ is arguable that both quantitative and qualitative methods have strengths and weaknesses, and therefore a mixed approach can be appropriate where results can be cross-checked.

However, for this study, the qualitative research methodology is considered more suited to capture the interrelated issues when seeking tax compliance perceptions. ${ }^{97}$ With this, the researchers adopted a taxpayer-centric view of tax compliance where the participants' perceptions of what tax compliance means for them was given prominence. Hence, to avoid imposing the researcher's a priori views on tax compliance, the quantitative method was not adopted. In particular, quantitative surveys were not used as they are unable to fully reflect the cognitive processes required to assess complex phenomena such as tax compliance. ${ }^{98}$ Furthermore, the small size and the scope of this study lends itself towards a qualitative study. Qualitative, semi-structured and in-depth face-to-face interviews with open-ended questions were employed to draw out the tax perceptions from the participants during 2007 to 2011, with selected follow-up interviews in 2013.

The participants for this study consisted mainly of two stakeholders: SME owner-managers and tax practitioners. Participants were sourced through a snowballing technique from the Auckland region as Auckland has the highest number of SMEs, as well as having one of the highest numbers of tax practitioners in New Zealand. ${ }^{99}$ This resulted in 43 purposive participants interviewed: 35 SME owner-managers and eight tax practitioners. SME participants were selected specifically based on their experience with tax compliance obligations. On the other hand, tax practitioners were selected if they had SMEs as their clients and were involved with managing their tax affairs. Since all the practitioners had multiple SME clients, it was found that saturation point was achieved with only eight practitioners with similar observations being raised. ${ }^{100}$ Purposive sampling was chosen to provide a rich setting in which in-depth information about perceptions and expectations of tax compliance could be unpacked concerning the central research question of the study. ${ }^{101}$ Basically, participants were sought and included in the sample for those who were willing to provide insights into their tax compliance perceptions and behaviours.

Open-ended interview questions were used with the participants as they allowed the researcher to enter the fieldwork without being constrained by predetermined categories of analysis. ${ }^{102}$ The participants were permitted to tell their experiences with tax compliance. Specific questions for the SME taxpayers explored their tax compliance perceptions, expectations and practices. The questions for the tax practitioners explored their tax compliance perceptions and the tax compliance practices of their SME clients.

95 In the context of the ATO and Inland Revenue, it is known as BISEP, which is part of the Compliance Model. BISEP stands for business, industry, sociological, economic and psychological factors that influence taxpayers' decisions and behaviour. The Compliance Model is based on academic research by V Braithwaite and J Braithwaite from Australian National University (ANU) in 2000. Since 2015, Inland Revenue has modified their Compliance Model to be more customer centric.

96 Erich Kirchler The Economic Psychology of Tax Behaviour (Cambridge University Press, Cambridge, 2007).

97 John Creswell Research Design: Qualitative, Quantitative, and Mixed Methods Approaches (4th ed, Sage Publications, Thousand Oaks, 2014).

98 Erich Kirchler "Differential representations of taxes: Analysis of free associations and judgements of five employment groups" (1998) 27 The Journal of Socio-Economics 421.

99 Inland Revenue "Number of clients of tax agents by geographic area 2008 to 2017" < https://classic.ird.govt.nz/>; and Ministry of Economic Development, above n 4.

100 Janice Morse “The Significance of Saturation” (1995) 5 Qualitative Health Research 147.

101 Giampietro Gobo “Sampling, Representativeness and Generalizability” in Clive Seale and others (eds) Qualitative Research Practice (Sage Publications, Thousand Oaks, 2007) 405.

102 Jane Baxter and Wai Fong Chua “The Field Researcher as Author-Writer” (2008) 5 Qualitative Research in Accounting and Management 101. 
The interviews were recorded, transcribed and then analysed for themes. The analysis of the findings follows a path as suggested by O'Dwyer involving data reduction, data display, and data interpretation and conclusion drawing. ${ }^{103}$ This method is an adaptation of the analytical process developed by Miles and Huberman, ${ }^{104}$ involving a three-stage process:

- Data reduction: Provides a general overview of the data collected and loosely classifies any emerging themes. It also involves reflecting on the data after a time lag to identify any commonalities in the participants' accounts.

- Data display: Involves mind-mapping of all the tax compliance factors identified from the data reduction stage with links between the factors. Formal coding and comparative core codes using matrices are found in this stage.

- Data interpretation and conclusion drawing: This involves examining the data holistically to create the "big picture". Any “outliers" that may challenge the big picture will also be noted. Thick description of the participants' accounts and selected quotes from participants will also be included.

According to Kirchler, the use of free association to study tax mentality was an early approach to uncover social representation. ${ }^{105}$ The method was based on the assumption that associations which came spontaneously to people's minds would display the nucleus of their representation, which accords with social representation.

\subsection{FINDINGS AND DISCUSSION}

The discussion of the findings compares and contrasts the perceptions and practices of tax compliance by the SME taxpayers and that of tax practitioners. Each SME taxpayer was asked about their perception of tax compliance. An analysis of the transcribed interview notes suggest that tax compliance has been perceived and associated with four major factors: legal, compliance costs, economic and other parties. These factors were then compared with the definition of "tax compliance" by Ohms, Olesen and Khin-Carter: ${ }^{106}$ see Table 7. The definition of tax compliance by Ohms, Olesen and Khin-Carter focuses on legal factors, compliance cost (especially paper work) and economic factors (especially paying tax). However, SMEs' perception of tax compliance is beyond these factors. Hence, it suggests that other factors are influencing SMEs' tax compliance behaviour, as shown in Table 7.

Table 8 details the perceptions of the $35 \mathrm{SME}$ taxpayers regarding tax compliance. These perceptions were largely negative as most perceived tax compliance as impositions on them, which cost them time, money and stress. Tax compliance is seen as tax obligations involving significant paperwork and tax payments. Many do not perceive any managerial benefits derived from tax compliance activities. ${ }^{107}$ The negative perceptions towards tax compliance confirmed the research findings in Australia and the United Kingdom. ${ }^{108}$ Table 9 details the perceptions of the eight tax practitioners in terms of tax compliance using the categories formulated from the SME analysis. These tables are then followed by a detailed analysis of the perception factors identified.

103 Brendan O'Dwyer "Qualitative Data Analysis: Illuminating a Process for Transforming a 'Messy' but 'Attractive' 'Nuisance'” in Christopher Humphrey and Bill Lee (eds) The Real Life Guide to Accounting Research: A Behind-The-Scenes View of Using Qualitative Research Methods (Elsevier Science, 2004) 391.

104 Matthew Miles and A Michael Huberman Qualitative Data Analysis: An Expanded Sourcebook (Sage Publications, Thousand Oaks, 1994).

105 Kirchler, above n 96; and Kirchler, above n 98.

106 Ohms, Olesen and Khin-Carter, above n 35.

107 Lignier, above n 74.

108 Melissa Belle Isle, Brett Freudenberg and Richard Copp "Cash flow benefit from GST: Is it realised by small businesses in Australia?" (2014) 29 Australian Tax Forum 417; and OECD, above n 2. 
Table 7: SME Perceptions of Tax Compliance

\begin{tabular}{|c|c|c|}
\hline $\begin{array}{l}\text { SME Perceptions of Tax } \\
\text { Compliance }\end{array}$ & $\begin{array}{l}\text { Compared to Tax } \\
\text { Practitioners }\end{array}$ & $\begin{array}{l}\text { Compared to Ohms, Olesen and } \\
\text { Khin-Carter, } 2015 \text { Definition of Tax } \\
\text { Compliance }\end{array}$ \\
\hline \multicolumn{3}{|c|}{ 4.1 Legal factors (see discussion in Section 4.1) } \\
\hline $\begin{array}{l}\text { Obligation, legal requirements } \\
\text { and complying with the law } \\
\text { (Legal factors) }\end{array}$ & Observed & $\begin{array}{l}\text { Set of statutory obligation (see discussion } \\
\text { in Section 2) }\end{array}$ \\
\hline $\begin{array}{l}\text { Do everything correctly, } \\
\text { accurately and on time (Legal } \\
\text { factors) }\end{array}$ & Observed & $\begin{array}{l}\text { Participate in any post-assessment } \\
\text { adjustment process (audit and dispute } \\
\text { resolution) }\end{array}$ \\
\hline \multicolumn{3}{|c|}{ 4.2 Compliance costs factors (see discussion in Section 4.2) } \\
\hline $\begin{array}{l}\text { Paperwork, tax returns, } \\
\text { accounting and accountants } \\
\text { (Compliance costs) }\end{array}$ & Observed & Register, record and report, return \\
\hline $\begin{array}{l}\text { Stress, difficulty and } \\
\text { overwhelming feelings } \\
\text { (Psychological compliance costs) }\end{array}$ & Not observed & \\
\hline \multicolumn{3}{|c|}{ 4.3 Economic factors (see discussion in Section 4.3) } \\
\hline Paying taxes (Economic factors) & Observed & $\begin{array}{l}\text { Of their annual total tax liability } \\
\text { enable assessment, pay }\end{array}$ \\
\hline Penalties (Economic factors) & Observed & \\
\hline \multicolumn{3}{|c|}{ 4.4 Other party factors (see discussion in Section 4.4) } \\
\hline $\begin{array}{l}\text { Inland Revenue (Tax authority) } \\
\text { and bureaucracy (Trust in } \\
\text { authority) }\end{array}$ & Observed & $\begin{array}{l}\text { Participate in any post-assessment } \\
\text { adjustment process (audit and dispute } \\
\text { resolution }\end{array}$ \\
\hline $\begin{array}{l}\text { The unfairness of tax system, } \\
\text { power imbalance, no distinction } \\
\text { made between SMEs and larger } \\
\text { enterprises (Fairness) }\end{array}$ & Not observed & \\
\hline
\end{tabular}



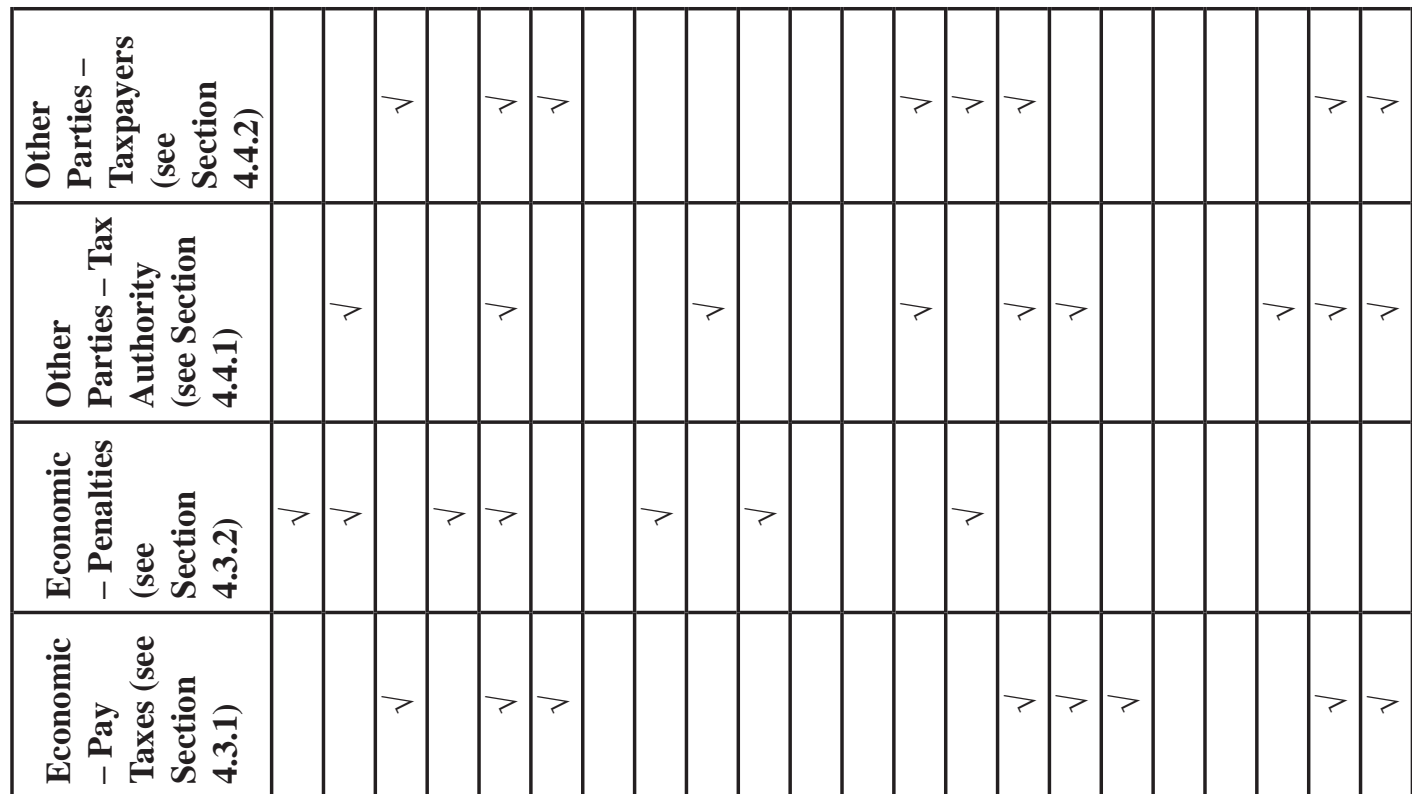

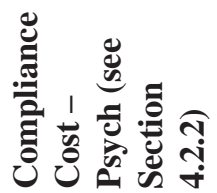

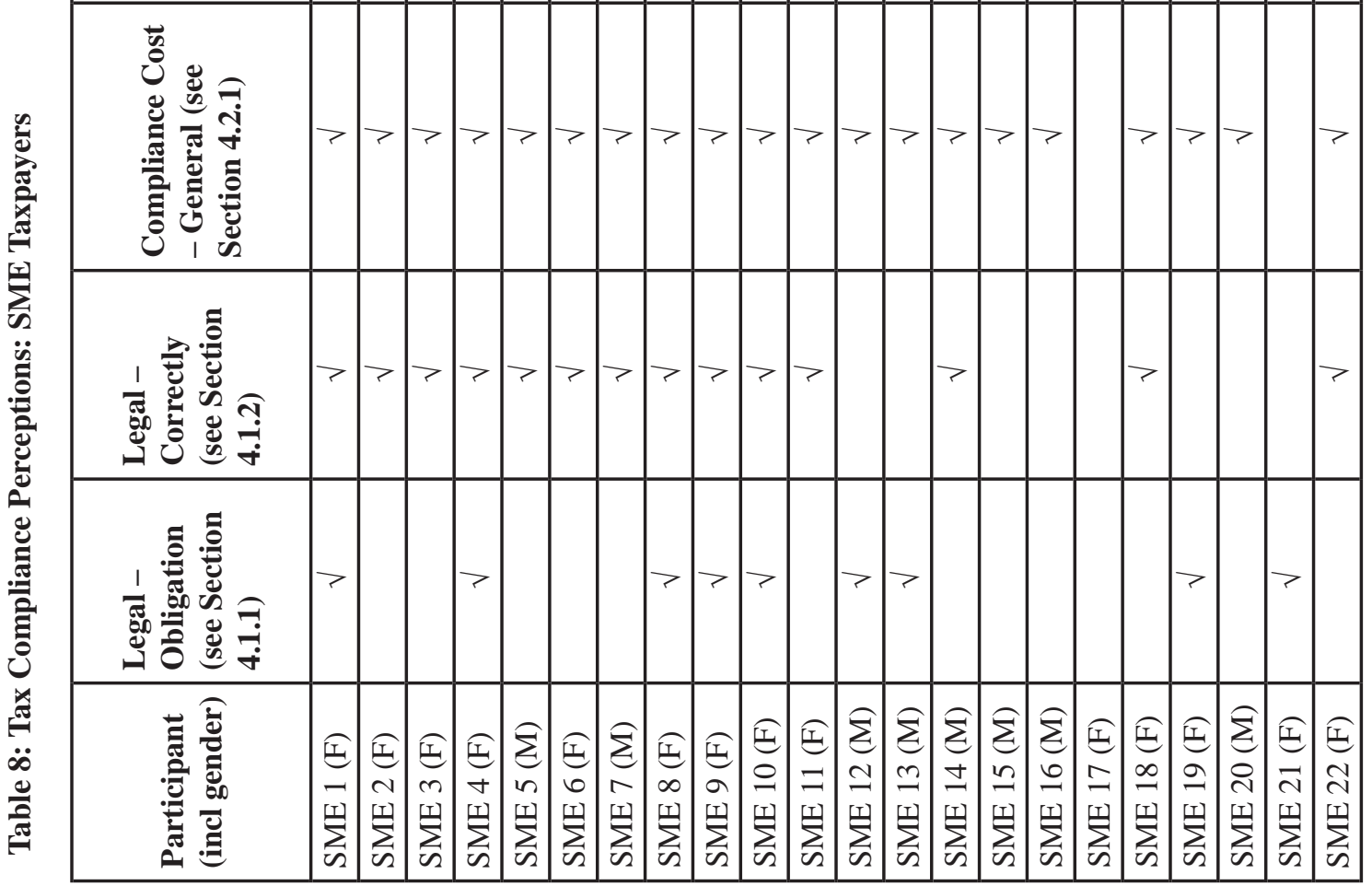




\begin{tabular}{|c|c|c|c|c|c|c|c|c|c|c|c|c|c|c|c|}
\hline 至 & & $>$ & $>$ & & & & $>$ & & $>1$ & $>1$ & & & & 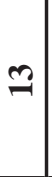 & $\frac{\stackrel{0}{\hat{m}}}{\mathrm{~m}}$ \\
\hline 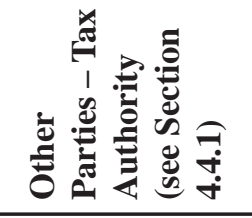 & & $>$ & $>$ & & & $>$ & & $>1$ & & & $>1$ & $>$ & & $\stackrel{2}{\sim}$ & $\begin{array}{l}\stackrel{0}{0} \\
\dddot{y}\end{array}$ \\
\hline 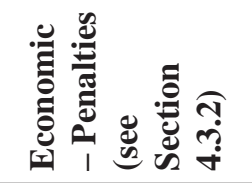 & & & $>$ & & & & & & & $>1$ & & & & $\sigma$ & $\begin{array}{l}\text { do } \\
\text { సै }\end{array}$ \\
\hline 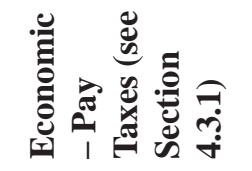 & & $>$ & & & $>$ & $>$ & $>$ & & & $>$ & $>1$ & & & $\Xi$ & ஓ̊ \\
\hline 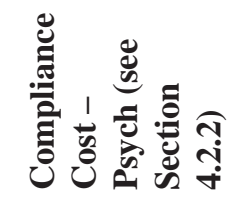 & $>$ & & & & & & $>$ & $>1$ & & & & $>$ & $>1$ & 으 & ब̊ \\
\hline 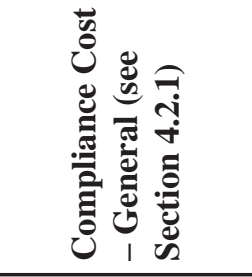 & $>$ & $>$ & & $>$ & $>$ & $>$ & $>$ & $>$ & $>1$ & & $>$ & $>$ & $>$ & $\vec{m}$ & $\begin{array}{l}\stackrel{0}{0} \\
\text { வ }\end{array}$ \\
\hline 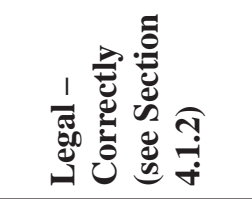 & & & $>$ & & & $>$ & $>$ & & & & $>1$ & & $>$ & 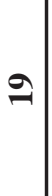 & 告 \\
\hline 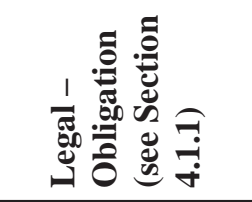 & & & & $>$ & & & & & & $>1$ & $>1$ & & & $\simeq$ & 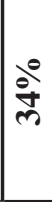 \\
\hline 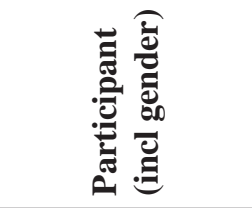 & 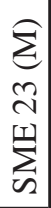 & 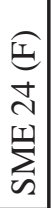 & 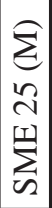 & 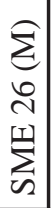 & 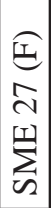 & 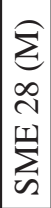 & 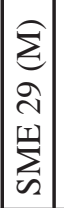 & $\begin{array}{l}\sum_{2} \\
0 \\
m \\
\sum_{\infty}^{1} \\
\text { In }\end{array}$ & 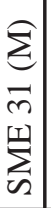 & $\begin{array}{l}\text { If } \\
\tilde{m} \\
\sum_{\infty}^{1}\end{array}$ & $\begin{array}{l}\underbrace{}_{m} \\
m \\
m \\
\sum \\
\sum \\
m\end{array}$ & 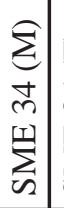 & 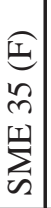 & 胥 & $0^{\circ}$ \\
\hline
\end{tabular}




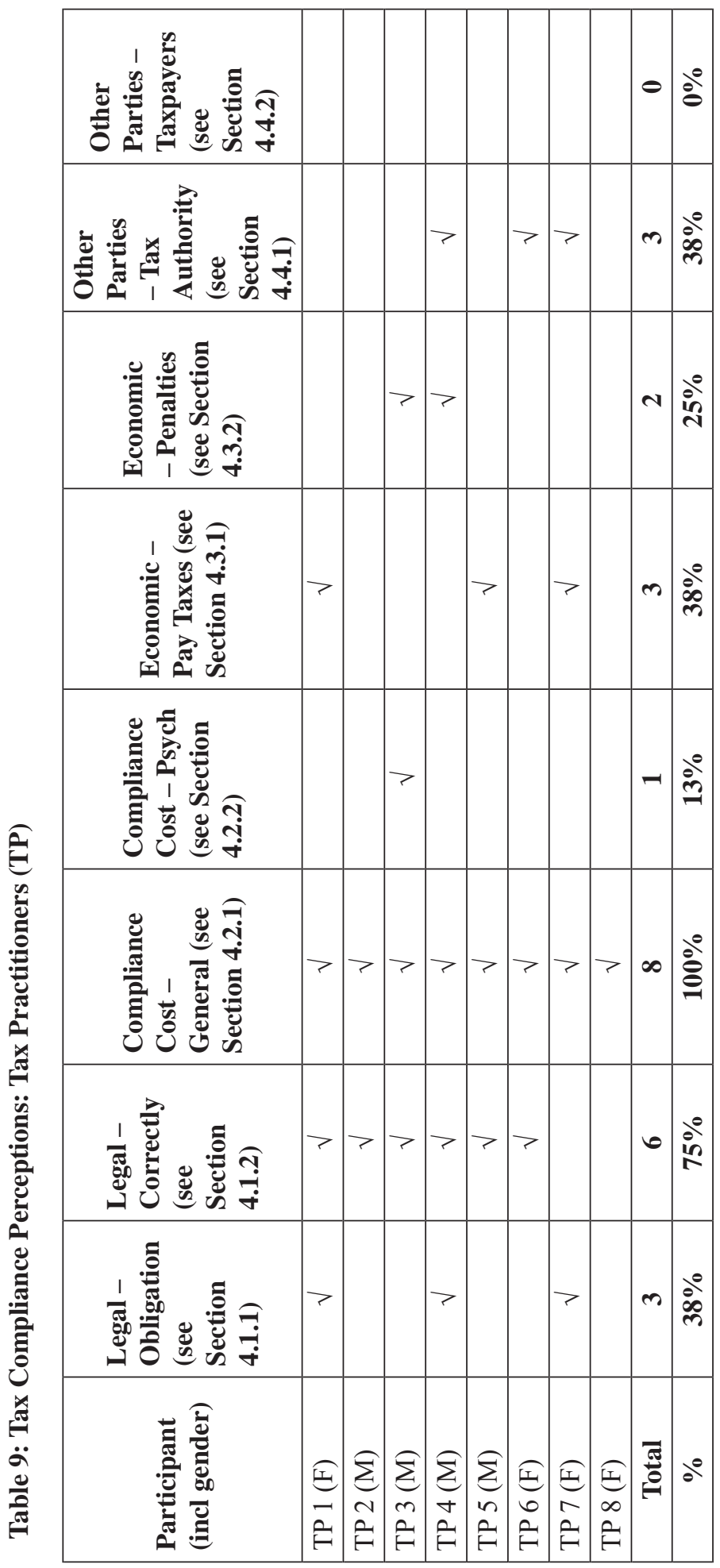




\subsection{Legal Factors}

\subsubsection{Obligation, legal requirements and complying with the law}

Thirty-four per cent of SMEs and 38 per cent of tax practitioners perceive tax compliance as fulfilling their legal obligations. This may demonstrate that explicit legal compliance with the law is taken for granted for many SMEs and their tax practitioners. However, this needs to be balanced with the high implicit legal obligation in terms of "Do everything correctly, accurately and on time" (see 4.1.2). SME taxpayers acknowledge that tax obligations are non-negotiable government impositions, thus affecting their intrinsic motivation to comply:

Actually we have to comply with tax because we have to. (SME 1)

Meeting your obligations and I don't have a problem in doing it, but sometimes it is difficult to find the time to do it as other things need to be done first. There are other times it feels like you have a mountain of stuff to comply, and that can be daunting at times. (SME 12)

It means paperwork, time-consuming paperwork, a legal obligation to file tax returns. (TP 4)

My clients do see tax compliance as a lot of work to file the tax returns and that it is a legal obligation to do so ...

Tax compliance undoubtedly involved the IRD, and to me, it is a government department serving a function. (TP 4)

The above accounts highlight the lack of choice given in terms of tax compliance. Failing to comply invites backlash from the tax authority, of which SMEs want to avoid. As a result of this, it may inadvertently force SMEs to be tax compliant.

\subsubsection{Do everything correctly, accurately and on time}

Fifty-four per cent of SMEs and 75 per cent of tax practitioners view tax compliance as filing accurate and timely tax returns. Tax practitioners' focus on accuracy and timing is crucial as that is their core profession. It is also their responsibility in ensuring their clients' tax records are accurate. Unfortunately, many SMEs do encounter complicated tax rules, thus hindering their ability to provide accurate records:

It means filing in the income tax, GST correctly and on time. Following the rules correctly for GST or pay your tax... It is not easy to understand what is deductible and what is not even-though I did attend some courses, and it seemed to open up a can of worms. Some of the rules can be too detailed. (SME 3)

To file all necessary tax returns on time and accurately. Compliance to me means form filling for tax returns, whereas the payment of taxes relates to budgeting and financial planning. (TP 1)

Tax compliance to me means IRD, paperwork, accounts, financial statements that are correct and on time and being tax agents, people have got one year to do their accounts. (TP 6)

When items 4.1.1 and 4.1.2 are considered together, most SMEs (34 per cent and 54 per cent) and tax practitioners ( 38 per cent and 75 per cent) consider the legal requirements to be one of the most influential tax compliance factors. Most SMEs perceived tax compliance to be difficult and time-consuming. They do not fully comprehend the tax legislation and are therefore reliant on their tax practitioners for year-end income tax returns. They assumed their tax practitioners would sort out errors on their tax returns filed during the year. This finding aligns with previous research by Tan that tax practitioners were employed in New Zealand to file 
more difficult returns such as income tax. ${ }^{109}$ Most SMEs would try to file their tax returns accurately and on time, but business and personal circumstances sometimes interfered with the process.

\subsection{Compliance Costs}

\subsubsection{Paperwork, tax returns, accounting and accountants}

Some SME taxpayers struggled to fulfil their tax obligations. Many felt inadequate due to lack of accounting knowledge and therefore question their ability to file accurate tax returns. The high number of tax returns required was also another salient point. Tax compliance involved long hours completing tax tasks with no perceived returns to them:

In terms of complying with the tax requirements, I find that we had to put in long hours to get the accounting information and can't see the returns of it. I had to give up other duties like selling and get all the accounting information right. (SME 10)

The need to have accurate accounting records is important not only for tax purposes but also for managerial benefits. Unfortunately, many do not value the importance of accounting records. Instead, some observed that tax does more harm to their business:

If you look at that perspective with GST, that is pretty unfair. There is no benefit for us to do the GST, and it makes a mess out of your books. The receipts that you are constantly keeping for the GST and even for the small expenses are just ridiculous. I have to have those receipts for seven years, and I count those seven years. (SME 31)

Even though GST returns are more frequent and should provide some insights, some SMEs do perceive GST as confusing and messing up their accounting information. Such observations are opposed to the idea that tax compliance can provide potential managerial benefits. Such negative perceptions of tax compliance would impede the notion of managerial benefits associated with tax recording. Others saw tax just as part of the normal incidence of running a business:

Tax compliance is part of being in business (SME 20)

However, there were concerns expressed about the poor or no record-keeping of SMEs by tax practitioners. Lack of evidence for record-keeping or deliberately claiming personal expenses as business expenses were common mistakes made by SMEs:

Majority of them (SMEs) are bad bookkeepers more like the shoe box. The shoe box mentality is those that have all the information, and we will sort them out. Some are so flustered with the whole process that they can't even collect the information for us. They may lose their receipts or toss their receipts somewhere ... Sometimes they may say some items are business, but we know that it is not. We will be very ruthless and still classify them as personal in their accounts, such as their medical bill. Each person is different, and we will deal with them differently. (TP 7)

Well because they (SMEs) have no idea of what tax they should be paying and the question of assessable income they just rely on their bank account. And when they pay something, that changes the whole picture, and they look at the tax payment as a cost of the business as almost completely disassociated from the operation of the business... They also used a lot of cash for their expenses and did not keep the receipts. I can see that they must have incurred the expenses, for instance, motor vehicle expenses ... but they cannot substantiate them, and they come to us after 18 months because of tax. And when we do the accounts, we found a substantial amount of cash drawings with very little expenses. (TP 3 )

109 Tan, above n 93; and Lin Mei Tan "Research on the Role of Tax Practitioners in Taxpayer Compliance: Identifying Some of the Gaps" in Adrian Sawyer (ed) Taxation Issues in the Twenty-First Century (University of Canterbury, Centre for Commercial and Corporate Law, Christchurch, 2006) 15. 
Most tax practitioners noted the level of ignorance (low tax literacy) of SMEs towards their tax obligation. With that, a significant number of SMEs in this study sought assistance from their tax practitioners regarding their tax obligations as they were not confident with their tax returns. As a consequence, it appears that SMEs are reliant on their tax practitioners in ensuring that their tax records were filed accurately and on time. TP 5 and TP 4 suggest that the compliance process can be made easier with a good accounting and administrative system:

Tax compliance is part of a good accounting system. If they [SMEs] have a good accounting system, tax compliance and getting the information for the tax returns will take less than 2 minutes. (TP 5)

For some of them, juggling between having to earn the income and finding time for administration and accounting stuff is a big issue. It depends on their level of computer literacy. (TP 4)

These quotes highlight how technology could reduce compliance cost and how improved computer literacy may ease tax compliance obligations. However, the success of such computer systems depends on tax literacy and record-keeping practices of SMEs:

Not many small businesses are excellent bookkeepers so basically before they go into business, there should be some kind of associations that will teach them the basic recording keeping for their business... They also ought to know about tax categories e.g. GST using invoice or cash basis and what happens if you do not have the invoice for GST. Another example is the depreciation rates for tax. (TP 2)

It is interesting to note that most tax practitioners failed to discuss the managerial benefits associated with tax compliance activities. Tax practitioners are important facilitators, and they influence SMEs in terms of compliance and record-keeping. In particular, tax practitioners could play a vital role by operating beyond the compliance role to add value to SMEs by promoting the use of financial records for businesses. Tax practitioners' inability to add value to SMEs may be due to fee constraints and the ongoing requirements to file tax returns, which mean little time for reflection:

Too many tax returns to do but have to do them. Just done one and another return is due soon. People (SMEs) don't understand the difference between them. For the tax practitioner/agent, the tax returns are not unduly complicated, but for some taxpayers, they find them difficult to understand. (TP 1)

Without tax practitioners taking an active role, it is difficult to see how SMEs will improve their perceptions of tax compliance when SMEs are not informed of the managerial benefits of tax compliance activities. This is important as most SMEs are shown to have low tax literacy and are dependent on their tax practitioners. Suggestions and free information from Inland Revenue regarding the managerial benefits of tax compliance activities may be of help, but such Inland Revenue recommendations may have little traction given SMEs' low tax literacy, reluctance to contact Inland Revenue directly, and the perception of a lack of expertise for Inland Revenue to give “business” advice

\subsubsection{Stress, difficulty and overwhelming feelings (psychological compliance costs)}

Some SMEs were unsure as to whether they had met all the tax requirements. Hence, tax compliance can be stressful and costly, consuming valuable SME resources that could otherwise have been devoted to their businesses. Most SMEs view their tax liability as an increasing burden, and they are not adequately trained to handle all compliance issues, and often penalties are involved:

I tried to talk to my accountant, and he confuses me more. If I go and see the accountant, I will leave that place so depressed, and it cost me as well. (SME 24) 
Half the time, I can't even get on with my work because I have to worry about the different types of taxes to pay and to account for them. Actually, in small businesses, I have to multitask, and the area that I am less skilled in is tax and the administration side and cash flow management. (SME 20)

Headaches, worry, fear because I have heard that they (Inland Revenue) can be quite hard on you and they go by the books... It is a force that you have to take it quite seriously and make sure that you are doing everything alright. (SME 34).

Twenty-nine per cent of SMEs noted the psychological costs with tax compliance, whereas few tax practitioners perceived tax compliance as stressful. Those SMEs who experienced the stress of compliance are those with poor record-keeping processes; they therefore felt uncertain regarding the accuracy of their tax records. Similarly, this view is observed by the tax practitioners. It may be that some did not raise the notion of "stress" because they had not considered tax in this way (and see it as just a normal consequences of running a business). ${ }^{110}$ According to tax practitioners, the root cause of the stress associated with compliance for SMEs is related to poor record-keeping and weak tax literacy:

I think the fear of the small business in dealing with the IRD comes from the uncertainty of not knowing what the obligations are. There are a lot of people who do not understand what a provisional tax is. Some (SMEs) will tell you that the business is not doing well and ask whether there is any way to reduce it. Some will ask what the provisional tax is for. (TP 3 )

Based on the evidence, there is a need for tax practitioners to be proactive and sensitive to the needs of SMEs by reducing the stress of compliance by ensuring a good record-keeping system, as well as aiding the financial and tax literacy of their clients. However, it is not clear whether tax practitioners are fully cognisant of their role in this regard. Due to their reliance on tax practitioners, SMEs appear more likely to heed the advice of their tax practitioners regarding their tax responsibilities. While it is the responsibility of SMEs to get the required training themselves, they may have capacity constraints (both in terms of time and/or financial). While there is the potential for free training and information, such as from Inland Revenue, some SMEs may be reluctant or unaware. It should be recalled the level of stress by business size shows that micro-businesses (1 to 5 employees) had the highest level of stress compared to others. This is also compounded by the fact that Inland Revenue is the government department requiring the most effort: see Table 5 .

\subsection{Economic Factors}

\subsubsection{Paying taxes}

Tax involves loss of money for the taxpayer; approximately 40 per cent of both SMEs and tax practitioners perceived tax compliance as an outgoing cost with a loss of cash flow. Tax compliance also conjures up bureaucracy, inefficiency and red tape. There is a greater tendency for SMEs to make tax payments at year-end due to gross incomes received. SME 5 and SME 24 resented paying taxes due to these sentiments:

Tax compliance will cost me a fortune, it is like going to the dentist, it will cost me money, and it is something you want to avoid and want to put it in the back burner, and then you have the penalties for doing so. Tax compliance to me is like a dirty word. For me, it is about inefficiency, dealing with the Government, bureaucracy...Tax compliance means that you have to get things right. It means lots of paperwork, accounting, and that's part of the problem. (SME 5)

110 Faridy and others, above n 48, at 184. 
Being ripped off. Yes, I see paperwork, the IRD and that cash flow is leaking out from the business... I feel absolutely sick when I have to pay taxes. We get so excited about getting the work, and by the time we pay all the taxes like GST and Income Tax, it is all gone. (SME 24)

The resentment towards paying taxes can be largely due to financial constraints faced by SMEs. Every tax dollar remitted would lead to fewer resources for their business. It should be recalled that this cost of tax may be difficult for SMEs, with them accounting for approximately one-third of unpaid debt. ${ }^{111}$ On the other hand, tax practitioners perceived this economic cost was attributable to poor budgeting and tax provisioning:

Some small businesses do not keep separate their bank accounts for personal and business and this can be problematic. Also, if they don't have the budget for GST, which can be substantial for those that only do the return every six months, this can be problematic. (TP 1)

Majority of them (SMEs) find the tax system is very unfair on them because it is a money issue. What goes to the IRD does not go to their bank account, and therefore it lowered their standard of living for them. To be fair to some of them, taxes have put a lot of strain on them. They need to put a lot of effort into the collection and administration of taxes like the GST and the provisional taxes. It is very difficult for them to comply and do the right thing. Most small businesses are not "systems" people when it comes to office work. It is just too much for them. (TP 7)

\subsubsection{Penalties}

About one-quarter of SMEs and tax practitioners noted the role of tax penalties as part of the economic costs of tax compliance. Cuccia found that increased penalties for tax practitioners had some effect on their efforts in identifying legitimate ways to reduce their clients' tax liability while having little effect on how aggressively they interpret ambiguous tax issues. ${ }^{112}$ Similarly, Devos and Kenny have found that the level of penalties imposed under the Code of Professional Conduct appear to influence tax practitioners' perceptions and therefore their own compliance. ${ }^{113}$ Furthermore, LaRue and Reckers found that the level of experience of tax practitioners and the opportunity for tax savings at year-end payments were important in determining the level of aggressive advice given to clients. ${ }^{114}$ As for this study, a motivator for tax compliance (or maybe more of a deterrent) for SMEs would be the potential application of penalties. This aligns with Inland Revenue's report that one-third of the tax debt owed by SMEs is made up of penalties and interest: ${ }^{115}$

The penalties for the mistakes made and much more paperwork. We want to comply if it is straight forward and we would like to think that we are doing the right thing. (SME 14)

The annual tax returns for companies and individuals, the GST returns for all NZ businesses. The fear of penalties and people see it as a cost of business. (TP 3 )

Complex tax rules can make the compliance process very arduous for SMEs. SMEs may resort to expert help, thus raising the tax compliance costs. To address this concern, the Government has undertaken several tax simplifications exercises. ${ }^{116}$ Despite these efforts, SMEs still struggle with the tax rules. It confirms the research that complex tax rules had an impact on compliance behaviours. McKerchar found that tax

111 Inland Revenue, above $\mathrm{n} 40$.

112 Andrew Cuccia "The Effects of Increased Sanctions on Paid Tax Preparers: Integrating Economic and Psychological Factors" (1994) 16 Journal of the American Taxation Association 41.

113 Devos and Kenny, above n 83.

114 D LaRue and P Reckers “An Empirical Examination of the Influence of Selected Factors on Professional Tax Preparers' Decision Processes" (1989) 7 Advances in Accounting 37.

115 LaRue and Reckers, above n 114.

116 Michael Cullen, Paul Swain and John Wright More time for business: Tax simplification for small business - A Government discussion document (Inland Revenue Department, May 2001). 
complexity can cause unintentional non-compliance amongst taxpayers. ${ }^{117}$ SME 4 best sums up the general perception of tax compliance for SMEs:

It is something that you have to do, regardless of how you feel about it. Tax compliance means that the company is under scrutiny to make sure that what we do is correct and that we are following the rules. It got to be accurate and correct. It also has to be on time. Because of the fee structure on penalties, it can be very stressful if you do not pay on time and you get the penalties ... Tax compliance means that I have to be organised, pay attention to the details, paperwork, making sure that I haven’t forgotten something. (SME 4)

Hence, tax penalties add to the stress and resentment towards the tax authority due to the perceived "unfairness". Other perceptions of unfairness relate to SMEs not being compensated for collecting taxes on behalf of the Government. Instead, they were penalised for being late or filing inaccurate returns:

In terms of all the compliance that we do, we should be rewarded for that. If we don't do the work we end up in jail. So basically that is our incentive. If we don't do the tax compliance, it is more the fear because you get hit with this big fine and they send us this letter you get a $\$ 100,000$ fine. Like the GST returns if you don't file a return, your first offence is 12 per cent and then the next is 100 per cent or whatever it is. (SME 29)

I think it is difficult because you have got your PAYE every 20th of the month and you have got your GST every two months... they penalised you if you don't do it (SME 33)

SMEs perceived the unfairness of penalties for mistakes and late lodgement. Tax penalties are perceived to be harsh and excessive, and most SMEs tried their best not to incur them. To them, penalties are especially acute since there is no real reward (positive acknowledgement) for doing things on time or correctly. SMEs are required to comply with the tax laws, and they do so to avoid penalties. However, there is an expectation by the SME sector to be compensated for their tax collection efforts. Unfortunately, this expectation may not materialise as the Government and Inland Revenue may not want to reward SMEs for just complying with the laws (particularly as other taxpayer groups are not). Furthermore, there exists the potential for managerial benefits from tax compliance activities even though SMEs may not acknowledge the existence of it.

\subsection{Other Parties}

\subsubsection{Inland Revenue (tax authority) and bureaucracy (trust in authority)}

Approximately 40 per cent of both SMEs and tax practitioners noted the role of the tax authority in tax compliance. This is important as the tax authority can either aid or hinder tax compliance. Furthermore, the way the tax authority conducts itself could influence perceptions/attitudes towards tax compliance as suggested by prior research on tax morale and the slippery slope framework. ${ }^{118}$ Perceptions of unfairness also relate to not being compensated for tax compliance activities undertaken on behalf of the tax authority. Some SMEs see themselves as being used by the Government as an unpaid tax collector:

I think paying taxes is part of life and it is something that they (IRD) imposed on you from day one. I suppose it means that we have to comply with what they (IRD) want and we don't have much of choice. There is a lot of paperwork involved, and I have a limited understanding of some of the paperwork. These involve a lot of time, and it is part of the compliance that we had to do for the IRD. We are "slaves" in collecting and administering the taxes like the GST for the IRD. We are not paid for doing all these. (SME 13)

117 McKerchar, above n 18.

118 Benno Torgler “Tax Morale, Rule-Governed Behaviour and Trust” (2003) 14 Constitutional Political Economy 119; and Erich Kirchler, Erik Hoelzl and Ingrid Wahl "Enforced versus voluntary tax compliance: The 'slippery slope' framework" (2008) 29 Journal of Economic Psychology 210. 
This account highlights the perception that SMEs are doing some of the work for the tax authority and it's largely unpaid - with a perception that their contribution to the administration of the tax system is not valued.

The fear of Inland Revenue as an authority figure was mentioned several times, especially when SMEs had to contact Inland Revenue. Lack of trust towards the tax authority was prominent for SMEs, which led them to distance themselves from the tax authority. The tax authority is generally viewed as an authoritative figure yielding excessive powers over them:

Don't get on the bad books with the IRD ... and the IRD is unforgiving and nasty. I think the main thing is that you worry about getting the wrong side with the IRD ... the penalties come on quite heavy and ruthlessly when you are filing late quite... Just dealing with them (IRD) is quite difficult. They are not helpful and that you are dealing with the bureaucracy. The telephone operator that you get now is a little bit more friendly but I supposed in the past they have come from a position of having the ultimate power over you and they are certainly not afraid to use it... sometimes you are too scared to contact the IRD because they may think that you have broken the law. (SME 25)

This negative perception prevents SME taxpayers from contacting the tax authority to clarify or resolve tax issues. Such avoidance tactics could escalate matters and make things worse, including incurring extra interest as observed by the tax practitioners:

No, I don't think small businesses have a good relationship with the IRD. I think there is a bit of feeling that once they (SMEs) are on the IRD records, they feel that they have the burden as far as the IRD is concerned. They (SME) don't feel comfortable dealing with the IRD and one of the reasons they hire the accountants is that they have the buffer of the accountant dealing with the IRD. They rather pay someone to deal with the IRD, and they prefer the accountant to get all the records and all the tax correspondence. (TP 3)

Tax practitioners also cautioned that Inland Revenue could provide inconsistent tax advice, thus discouraging SMEs from contacting Inland Revenue directly:

They (SMEs) want little to no contact at all with the IRD if they can help it. To get to the right person in the IRD if you have a query is difficult. You can be asking the same question, and two different IRD representatives can sometimes give you two different answers. (TP 2)

\subsubsection{The unfairness of the tax system, power imbalance, no distinction made between SMEs and larger enterprises (fairness)}

About 40 per cent of SMEs noted "other parties" which influenced their perceptions of tax unfairness. In comparison, this notion of unfairness was not raised by tax practitioners. SMEs felt that they were treated prejudicially as they were taxed the same income tax rate as larger enterprises. This perception of (un)fairness relates to both the level of taxation and government spending. Most felt that the tax rates should differ between SMEs and larger enterprises. Tax revenue wastages on welfare and social benefits were common complaints. SMEs viewed themselves as working hard for the country, but the Government failed to acknowledge their economic contributions towards society. Consequently, SMEs perceived the tax system had failed them.

Perceptions about tax unfairness were salient to taxpayers. ${ }^{119}$ Porcano and Price noted that there were several dimensions of tax fairness perceptions that concern both taxpayers and tax preparers. ${ }^{120}$ These dimensions were fairness perceptions about complexity, frequent changes in taxes, overtaxing, relief to the needy, incentives/disincentives to earn more, and aiding economic growth. Gerbing also identified eight

119 Lin Mei Tan “Taxpayers' Perceptions of Fairness of the Tax System: A Preliminary Study” (1998) 4 NZJTLP 59.

120 T Porcano and C Price "Some Evidence on the Association Between Judgement Criteria and Fairness Perceptions" (1992)

4 Advances in Taxation 183. 
main factors relating to fairness, which were: general fairness/distribution, exchange with the Government, self-interest, government spending, attitude towards taxes of the wealthy, progressive versus flat tax rates, complexity and justification of evasion. ${ }^{121}$ As for this present study, both SMEs and tax practitioners were largely concerned with three aspects of tax unfairness perceptions, namely: (a) tax rates; (b) lack of compensation for the work done on behalf of the Government; and (c) tax penalties. SMEs were dissatisfied that they had been charged the same high tax rates as larger businesses and that larger businesses were not paying their fair share of taxes:

It is not fair for small business tax. Those small businesses pay the same tax amount as the larger businesses... Like if we earn $\$ 50,000$ or $\$ 1,000,000$, we pay the same flat tax rate regardless of size. (SME 29)

I don’t think it is fair. Larger enterprises should pay a bit more than small businesses. The big businesses can get away without paying taxes... The government is not targeting those who are not paying taxes like big businesses because they (government) are afraid to tackle them and are lenient towards the big businesses. (SME 14)

I don't think it is overly fair for small businesses as there is no distinction made between the smaller businesses and the larger businesses in term of tax payments. The smaller businesses had limited resources and time to comply with the tax requirements. The 10 hours that I spent on the administration and collecting taxes for the IRD is a cost, and there is no return on that. For a larger business, they have the resources to do that. (SME 15)

In summary, the above findings demonstrate the behavioural and situational characters of SME taxpayers when considering tax compliance and how they are different from that of their tax practitioners. Tax compliance behaviour is a complex issue, comprising numerous variables, to which no all-embracing explanation has been developed. ${ }^{122}$ Nevertheless, by identifying relevant compliance variables pertinent to the stakeholder groups, it enables the tax authority, tax practitioners and academia to be informed when suggesting and making policy and practice decisions.

\subsection{ANALYSIS AND RECOMMENDATIONS}

The findings from this article have a strong practical orientation. The knowledge can be used in diverse ways and can have several implications and strategies, both long term and short term. It appears that there are more factors influencing tax compliance for SMEs; whereas, for tax practitioners, it is narrowly focussed on process and legislation. The tax profession perceives tax compliance as preparing accurate returns and paying correct tax liabilities, which requires good accounting systems and budgeting skills. ${ }^{123}$ On the other hand, SME taxpayers perceive tax compliance to be multi-faceted, including economic, structural, trust in authority, legal and psychological factors which confirms prior meta-studies by Richardson and Sawyer, ${ }^{124}$ Jackson and Milliron, ${ }^{125}$ and Andreoni, Erard and Feinstein. ${ }^{126}$

There appear to be some major differences between SMEs and tax practitioners' views on tax compliance. These differences relate to psychological, economic, structural and institutional factors. The current misconception is that the tax authority assumes that SME taxpayers should or ought to know about their compliance obligations, which involve record-keeping, accounting system and cash management skills. ${ }^{127}$ However, due to SMEs being small and having competing demands from suppliers, employees, debtors and

121 Monica Gerbing “An Empirical Study of Taxpayer Perceptions of Fairness” (PhD thesis, University of Texas-Austin, 1988).

122 Richardson and Sawyer, above $n$, at 144.

123 This confirms the findings from Evans, Carlon and Massey, above n 57.

124 Richardson and Sawyer, above $n 1$.

125 B Jackson and V Milliron "Tax Compliance Research: Findings, Problems and Prospects" (1986) 5 Journal of Accounting Literature 125.

126 James Andreoni, Brian Erard and Jonathan Feinstein “Tax Compliance” (1998) 36 Journal of Economic Literature 818.

127 Ahmed and Braithwaite, above n 13. 
government, SME taxpayers can only meet these demands when they have the time and resources to do so. Often, the working environment of SMEs is variable and demanding with limited resources. To SMEs, tax compliance is not a priority but rather obligatory, burdensome and yielding no positive returns. ${ }^{128}$

The importance of understanding the divergent perceptions of tax compliance helps with assistance, education and administration of SME taxpayers. Instead of punishing non-complying taxpayers, one should try to understand why they were not complying in the first place. Were they non-compliant because of their perceptions and the practicality of compliance rather than a deliberate intention not to comply? This could also consider whether there is a difference between SMEs and larger businesses. This gap needs to be addressed to reduce the burden and stress of compliance and to improve the tax morale for SMEs. ${ }^{129}$ This notion can also be applied to other non-SME taxpayers to identify the relevance of this tax misconception and the impact on their compliance behaviours.

Given the above accounts, there are several recommendations to improve the tax compliance of SMEs. First, there is fear and reluctance amongst SMEs to approach Inland Revenue for assistance. Instead, most SMEs approach their tax practitioners, but due to the high cost, that occurs infrequently. There is also a need to reduce the social distance between SMEs and the tax authority. Tax practitioners can bridge this distance by having effective communication between SMEs and Inland Revenue, helping to dispel any misconceptions about tax payments and returns, thereby reducing the tax compliance expectation gap.

Second, it is recommended that Inland Revenue needs to be more customer/service-oriented when dealing with SMEs by providing technical support in meeting tax obligations. ${ }^{130}$ This is because many SMEs distanced themselves from Inland Revenue due to lack of trust and fear. This is consistent with other findings showing that a significant majority of New Zealand individual taxpayers do not contact Inland Revenue. ${ }^{131}$ To address the issue, Inland Revenue could produce useful websites and use artificial intelligence programs to assist SMEs with simple questions. For example, the Australian Taxation Office has attempted to improve its relationship with small businesses by circulating monthly e-newsletters reminding them of upcoming lodgement requirements and any other useful links relating to their compliance obligations. ${ }^{132}$ Also, it has developed free software to assist with storing receipts for deductions. Such software may be particularly useful for business taxpayers as they are likely to have to store more receipts/documentation as evidence of their business transactions compared to individual taxpayers. This in part could assist with financial capacity constraints for SMEs (especially micro-businesses) to purchase such software.

Inland Revenue should also consider the option to waive or reduce penalties and fines for genuine mistakes and economic hardships, instead of using the traditional command and control option. A suggestion is that rather than always imposing interest and penalties, it may be preferable for Inland Revenue to have the option to waive or reduce such amounts and instead give a direction for an SME to undergo a relevant education course or implement certain systems. In this way, such expenditure by the SMEs could facilitate better knowledge and systems and improve compliance in the future, as well as create a better perception of tax compliance, especially regarding the relationship with Inland Revenue. Recently, in Australia, such an

128 Sylvia Yuan, Trudie Cain and Paul Spoonley Immigrant Entrepreneurship and Tax Compliance: A Literature Review (National Research and Evaluation Unit of the Inland Revenue Department and Massey University, June 2013); and Yong, Northcott and Hooper, above n 32.

129 Recep Yücedoğru and John Hasseldine “Understanding tax morale of SMEs: A qualitative study” (2016) 14 eJournal of Tax Research 531.

130 See Yong and Martin, above n 69; and A Hodson “Inland Revenue’s New Circular Compliance Model - An Overview” (2018) 13 Journal of the Australasian Tax Teachers Association 187 at 204.

131 Hodson, above n 130, at 194.

132 See: Australian Taxation Office "Small business newsroom" <www.ato.gov.au/>. 
education direction was part of legislation for superannuation breaches. ${ }^{133}$ Like Braithwaite has suggested, taxpayers should be regulated based on their motivational postures of commitment, capitulation, resistance and disengagement, and there needs to be a suite of regulatory measures instead of a one-size-fits-all approach. ${ }^{134}$ Penalties and fines should be reserved for persistent non-compliers who resist and are disengaged from the tax system.

Third, it is recommended that SMEs need greater resources and incentives to improve their accounting knowledge and administrative/budgeting skills, especially given the financial constraints they can face compared to larger businesses. For example, it has been argued that it is critical to provide a "professional advice rebate" to encourage SMEs to get professional advice early on in their business lifecycle. ${ }^{135}$ SMEs could be provided with a dollar-for-dollar rebate/refund (up to an annual cap) to cover the cost of seeking professional advice. This could, in part, be justified as a cost reimbursement by the Government to SMEs for their tax collection efforts. It can also be a signal by the Government that it encourages SMEs to seek professional accounting advice to improve on their accounting knowledge. On the other hand, individual taxpayers whose taxes are deducted at source are not required to file tax returns and therefore there is a lesser need for them to seek professional accounting advice.

Fourth, it is recommended that SMEs need to improve their accounting knowledge, systems and records. There should be incentives and assistance for SMEs to set up accounting systems, including informing them about the managerial benefits of accounting records. ${ }^{136}$ This can be resolved with encouragement, education and assistance from the tax practitioners. Any administrative assistance given to set up a sound accounting system for SMEs can potentially reduce the stress of filing tax returns. This will eventually free up SMEs to concentrate on building revenues and wealth for their business. Tax practitioners should also discuss the use of information generated by tax records and how they could be applied to benefit SMEs.

Fifth, to remedy the resentment towards paying taxes, the tax authority and tax practitioners need to (re-) educate SMEs regarding the purpose of tax and the importance of cash management skills. Having cash management skills may help SMEs to eschew costly tax penalties. For example, the Australian Taxation Office has developed a Cash Flow Coaching Kit for tax practitioners to develop their SME clients' cash flow management skills. ${ }^{137}$ Another example is budgeting training on cash management to be given to SMEs by the tax practitioners.

\subsection{CONCLUSION AND SUGGESTIONS FOR FUTURE RESEARCH}

This present study identified the differences in perceptions of tax compliance by SME taxpayers and tax practitioners. There were common themes perceived by these groups, being that tax compliance is a statutory obligation involving filing correct tax returns and paying their taxes on time. However, there are differences in attitudes towards tax compliance between SMEs and tax practitioners, thus resulting in a tax expectation gap. It also confirms that tax compliance is a complex phenomenon as it is dependent on human behaviour and the context in which it is applied. ${ }^{138}$

133 Such a "direction for education" was contained in Treasury Laws Amendment (2018 Measures No 4) Bill 2018, Part 2, which inserted a new s 8C(1)(f)(fa) into the Taxation Administration Act 1953.

134 Valerie Braithwaite “Responsive Regulation and Taxation: Introduction” (2007) 29 Law and Policy 3.

135 Freudenberg and others, above n 63, at 708.

136 Lignier, above n 74; and Belle Isle and Freudenberg, above n 7.

137 See: Tax \& Super Australia "Cash flow: It can be a make-or-break issue for small business" (12 June 2018) <https:// taxandsupernewsroom.com.au/>.

138 OECD, above n 62. 
SME taxpayers perceived tax compliance to be burdensome, costly and involving record-keeping. To them, the compliance process is to fulfil their tax obligations and not for managerial benefits. Tax compliance is also associated with tax payments and a loss of cash flows, thus limiting their entrepreneurial freedom and creativity. Tax compliance also conjures up the image of a power imbalance between SMEs and the tax authority. The lack of trust and uneasy relationship with the tax authority was a significant factor in shaping SMEs' compliance perceptions. This issue needs to be addressed; Torgler suggests that creating a positive attitude towards the tax authority will enhance compliance. ${ }^{139}$

The present study adds to the growing tax compliance literature by examining the tax compliance perceptions of both SME taxpayers and tax practitioners. It has been found that there are legal, economic, psychological, attitudinal and other parties involved, as perceived by these two stakeholder groups, in relation to tax compliance. It contributes to our knowledge of SMEs' attitudes towards tax compliance. It also extends the literature by identifying both SMEs and tax practitioners' perceptions of tax compliance. Each stakeholder group's responses were examined and contrasted to identify the gap. There are still important gaps in the literature concerning why SMEs remain one of the least compliant groups in most countries. For example, SMEs continued to be renowned for their participation in the shadow economy. ${ }^{140}$ Past research has not addressed the perception of tax compliance from this group; rather, it was assumed that they were not complying because of the perceived opportunity to evade taxes, there being no withholding taxes at source, and their participation in the cash economy. ${ }^{141}$ Furthermore, studies have shown that tax practitioners did exhibit marginal tax ethics and tax morale. ${ }^{142}$ This present study demonstrates that a possible explanation for SMEs' high non-compliance statistics may be due to the tax compliance perception gap between this sector and tax practitioners. Having this knowledge is valuable to practitioners and the tax authority in order to address SMEs' negative perceptions towards tax compliance.

The perceptions of SMEs and the tax practitioners though different, are not irreconcilable, provided each group accepts responsibility for their respective obligations. However, without mutual trust and understanding, reconciling the differences may be difficult to achieve. This is especially so with the trust deficit in the tax authority. While paying tax is a civic obligation for SMEs, it is important for the tax authority to lessen the burden of tax compliance for SMEs to instil higher voluntary compliance. This will only happen when the tax authority takes an interest in understanding SMEs and lessens the burden of compliance.

Given that this qualitative study was conducted based on purposive sampling, the interpretations and suggestions appearing in the analysis section need to be regarded as indicative rather than conclusive. Unlike quantitative methods, the aim of this research is not to generalise the findings to the wider population. Instead, it is to explore the issues which are salient to SMEs in terms of their perceptions of tax compliance. It also provided a contrast between two stakeholder groups in terms of their views on tax compliance. Hence, in order to be able to generalise to the wider population, there is a need to quantify the results of this qualitative study, something which is recommended for future research. Quantification would allow the results to be examined across a representative sample of SMEs in order to verify the different compliance

139 Benno Torgler “Tax morale and direct democracy” (2005) 21 European Journal of Political Economy 525.

140 OECD Forum on Tax Administration: SME Compliance Sub-Group - Reducing Opportunities for Tax Non-Compliance in the Underground Economy (OECD Publishing, Paris, 2012).

141 Susan Morse, Stewart Karlinsky and Joseph Bankman “Cash Businesses and Tax Evasion” (2009) 20 Stanford Law and Policy Review 37; and Azhar Mohamad, Mohd Hasrol Zakaria and Zarinah Hamid "Cash Economy: Tax Evasion Amongst SMEs in Malaysia” (2016) 23 Journal of Financial Crime 974.

142 Benno Torgler and Kristina Murphy “Tax Morale in Australia: What Shapes it and Has it Changed over Time?” (2004) 7 Journal of Australian Taxation 298; and Rebecca Attwell and Adrian Sawyer "The Ethical Attitudes of New Zealand Tax Practitioners — Still 'Barely Passing'?’ (2001) 7 NZJTLP 111. 
issues referred to in this study. This is because some compliance issues may be of more "value" to some SMEs than others. Particularly, future research could consider the role of SMEs' tax literacy in terms of its exact relationship with tax compliance. Future research could consider whether a return/bonus for SMEs who lodge and pay on time would improve perceptions (as well as tax compliance behaviour) over time.

This study provides important insights not only on the tax compliance of actual SME taxpayers but also on taxpayers' trust in government and the tax authority. ${ }^{143}$ The findings suggest that the lack of taxpayers' trust in government and authority were largely due to the lack of recognition of SMEs' economic contributions by the Government, fear of the tax authority and not being compensated for their collection efforts. The social distance between SMEs and the tax authority is also aggravated by the inconsistent advice given by Inland Revenue officials. By bringing together a unique collection of qualitative data, archival research and government documents, this study provides a further analysis of the perception gap. It also demonstrates that the perception gap may carry meaningful implications for the level of tax compliance as desired by the tax authority and tax practitioners. We live in a tax compliance expectation gap society, a gap of what we expect from SMEs and what SMEs experience with their tax obligations. Unless this gap is bridged, it may give rise to frustration, discouragement, and a low tax morale from the SME sector. The results point toward a complex picture of tax compliance, requiring a multifaceted policy approach that emphasises not only enforcement but also cognitive and affective aspects of human behaviour.

Accepted for publication on 12 September 2019

143 Torgler, above n 118. 
